\title{
Chemical Analysis of Vitamin D Insufficient and Vitamin D Deficient Patient in Dera Ghazi Khan
}

\section{Ayaz Ahmad*}

Department of Biology, Government Degree College, Block.no.17., Dera Ghazi Khan, Punjab, Pakistan

\begin{abstract}
Background: Among all vitamins, Vitamin $\mathrm{D}$ is important with respect to bone health and body immunity. Hypovitaminosis $D$ is a global health issue, and considered as an epidemic. The worldwide, a billion of people with hypovitaminosis $\mathrm{D}$ has been estimated, however, there are a limited number of studies has been conducted in third world countries to measure the Vitamin $D$ levels in their general population. This investigative study aimed to determine the prevalence of hypovitaminosis D in general population of District D. G. Khan, Pakistan

Methodology: After a personal visit in various hospitals, 100 patients with vitamin D deficiency and insufficiency were enrolled in the study. They full filling inclusion and exclusion criteria. After taking informed written consent, blood samples were drawn and examine the serum levels of 25-hydroxy vitamin $D$. The serum level of 25-hydroxy vitamin $D$ below $32 \mathrm{ng} / \mathrm{ml}$ is classified as Vitamin $D$ insufficiency, while below $20 \mathrm{ng} / \mathrm{ml}$ is Vitamin D deficiency.

Results: The mean age of 62 male (18-50) years and 38 females (18-50) years. Among these, serum 25(OH) Vitamin D means level of 62 male samples while 38 female samples were studied. The 27 males showed vitamin insufficiency, 25 males were Vitamin D deficient. Among 38 females, 11 subjects showed vitamin D insufficiency, 22 were vitamin $D$ deficient, while 10 males and 5 females were normal control. The male subject showed significantly low serum calcium and phosphorous level, but elevated alkaline phosphatase (ALP) level as compared to normal male control. Similar finding has been found in female subjects.
\end{abstract}

Conclusion: The vitamin D deficiency or insufficiency reduces the serum calcium and phosphorous level, while it causes elevation of serum ALP level.

Keywords: 25-hydroxy vitamin D; Alkaline phosphatase; Calcium; Phosphorous

\section{Introduction}

\section{Vitamin D}

Fat-soluble vitamin $\mathrm{D}$ has two forms, vitamin $\mathrm{D}_{2}$ and Vitamin $\mathrm{D}_{3}$. There are two main sources of vitamin $\mathrm{D}_{3}$, it is produced due to exposure of skin to UV (B) radiation or it is obtained through diet. While vitamin $\mathrm{D}_{2}$, found in a few plants also. Although both forms have same metabolic pathway, but it is found that vitamin $\mathrm{D}_{2}$ more rapidly metabolize as compared to vitamin $\mathrm{D}_{3}$. Although Vitamin $\mathrm{D}$ is essential for intestinal absorption of calcium, it has been found that level of the $25(\mathrm{OH}) \mathrm{D}$ must be higher than $32 \mathrm{ng} / \mathrm{mL}$ for the optimal absorption of calcium $[1,2]$.

\section{Materials and Method}

\section{Field work}

Patients were identified through personal visit in different areas of district D.G. Khan, the clinically diagnosed vitamin D insufficient and deficient patients were included in study. The physical symptoms were, i.e., fatigue, general muscle pain, weakness, joint pain, chronic pain, high blood pressure, restless sleep, headaches, urinary bladder problem, constipation and diarrhea. Preliminary information about the patients includes their contact number and postal address, etc.

Those patients were included in the study, which were diagnosed with vitamin $\mathrm{D}$ deficiency or insufficiency with no other reported disorder. The subjects were not included in the study if having; Anemia, genetic disorder, diabetes mellitus, cardiopulmonary disease, viral infection, bacterial infection and Malignancy [3-5].

\section{Collection of blood sample}

The five $\mathrm{ml}$ of peripheral blood sample was collected from each patient by using butterfly needle and sterile syringes. The blood samples were collected in plain tubes and tubes were allowed to stand for 30 min to blood clot, followed by centrifugation at $3000 \mathrm{rpm}$ for $10 \mathrm{~min}$ to separate serum. Each serum sample was immediately transferred into serum collection tubes labeled with patient identification codes.

1. The vitamin $\mathrm{D}$ quantification was performed through the Vitamin D test kit.

2. The serum calcium level was quantified through photometric system.

3. The serum phosphorus level was measured spectrophotometric ally. For this purpose serum phosphorus quantification Diagnostic system kit.

4. The quantification of serum alkaline phosphatase (ALP) level was carried out through in vitro diagnostic reagent photometric system kit.

\section{Results}

After a personal visit in various hospitals, 100 patients with vitamin $\mathrm{D}$ deficiency and insufficiency were enrolled in the study. They full filling inclusion and exclusion criteria. After taking informed written consent, blood samples were drawn and examine the serum levels of 25 -hydroxy vitamin $\mathrm{D}$. The serum level of 25 -hydroxy vitamin $\mathrm{D}$ below

*Corresponding author: AyazAhmad, Department of Biology, Government Degree College, Block.no.17, Dera Ghazi Khan, Punjab, Pakistan, Tel: +923346789348, E-mail: ayaz_sarkani@yahoo.com

Received March 23, 2018; Accepted April 10, 2018; Published April 17, 2018

Citation: Ahmad A (2018) Chemical Analysis of Vitamin D Insufficient and Vitamin D Deficient Patient in Dera Ghazi Khan. Mol Biol 7: 211. doi: 10.4172/21689547.1000211

Copyright: (C) 2018 Ahmad A. This is an open-access article distributed under the terms of the Creative Commons Attribution License, which permits unrestricted use, distribution, and reproduction in any medium, provided the original author and source are credited. 
$32 \mathrm{ng} / \mathrm{ml}$ is classified as Vitamin D insufficiency, while below $20 \mathrm{ng} / \mathrm{ml}$ is Vitamin D deficiency [6].

The mean age of 63 male (18-50) years and 37 females (18-50) years. The 27 males showed vitamin insufficiency, 25 males were Vitamin D deficient among 38 females. 11 subjects showed vitamin D insufficiency, 22 were vitamin D deficient, while 10 males and 5 females were normal control. The male subject showed significantly low serum calcium and phosphorous level, but elevated alkaline phosphatase (ALP) level as compared to normal male control. Similar finding has been found in female subjects [7-9].

The current section provided the research findings regarding the responses of the patients with respect to the research questions of the study. These responses were analyze by using the frequencies as well as by applying the tools of t-test and ANOVA application to find out the responses rate on the research questions and to reach the conclusion comprehensively. The table provided the data regarding the frequencies of the respondents with respect to the gender. The gender demographic variable was grouped into males and females. The table shows that there were total 100 respondents who participate in the current research study. The table further shows that there were total 62 male respondents while the female respondents were 38 [10].

In Table 1, the male participants are $62.0 \%$ which shows significant participation of males instead of females.

The data regarding the frequencies of the respondents with respect to the age is given in Table 2. The age demographic variable was grouped into 20-35, 36-45 and 46-60. There were total 100 respondents who participate in the current research study. The table further shows that there were total 38 respondents who have age in between 20-35. While the female respondents those who have age in between 36-45 were 31 . In the same line, the respondent with the age in between the 46-60 were also 31 .

Three age groups were studied in present study with different cumulative \%age.

Table 3 showing the vitamin $\mathrm{D}$ frequencies amongst the normal, deficient and insufficient participants.

\begin{tabular}{|c|l|c|c|c|c|}
\hline \multicolumn{2}{|c|}{} & Frequency & Percent & $\begin{array}{c}\text { Valid } \\
\text { Percent }\end{array}$ & $\begin{array}{c}\text { Cumulative } \\
\text { Percent }\end{array}$ \\
\hline \multirow{3}{*}{ Valid } & Male & 62 & 62.0 & 62.0 & 62.0 \\
\cline { 2 - 6 } & Female & 38 & 38.0 & 38.0 & 100.0 \\
\cline { 2 - 6 } & Total & 100 & 100.0 & 100.0 & \\
\hline
\end{tabular}

Table 1: The frequencies regarding the gender.

\begin{tabular}{|c|c|c|c|c|c|}
\hline & Frequency & Percent & Valid Percent & $\begin{array}{c}\text { Cumulative } \\
\text { Percent }\end{array}$ \\
\hline \multirow{4}{*}{ Valid } & $20-35$ & 38 & 38.0 & 38.0 & 38.0 \\
\hline & $36-45$ & 31 & 31.0 & 31.0 & 69.0 \\
\hline & $46-60$ & 31 & 31.0 & 31.0 & 100.0 \\
\hline & Total & 100 & 100.0 & 100.0 & \\
\hline
\end{tabular}

Table 2: The frequencies regarding the age.

\begin{tabular}{|c|l|c|c|c|c|}
\hline \multicolumn{2}{|c|}{} & Frequency & Percent & $\begin{array}{c}\text { Valid } \\
\text { Percent }\end{array}$ & $\begin{array}{c}\text { Cumulative } \\
\text { Percent }\end{array}$ \\
\hline \multirow{3}{*}{ Valid } & Normal & 15 & 15.0 & 15.0 & 15.0 \\
\cline { 2 - 6 } & Deficient & 38 & 38.0 & 38.0 & 53.0 \\
\cline { 2 - 6 } & Insufficient & 47 & 47.0 & 47.0 & 100.0 \\
\cline { 2 - 6 } & Total & 100 & 100.0 & 100.0 & \\
\hline
\end{tabular}

Table 3: The frequencies regarding the vitamin $\mathrm{D}$.
Table 4 showing the calcium frequencies amongst the normal, deficient and insufficient participants.

Table 5 showing phosphorous frequencies amongst the normal, deficient and insufficient participants.

Table 6 showing alkaline phosphatase frequencies amongst the normal, deficient and insufficient participants.

The data regarding the research questions given in Table 7 shows that the patients have different mean values of age, vitamin $\mathrm{D}$, calcium, phosphorus and alkaline phosphatase. Table 7 provided the data with respect to the total number (100), the mean and the standard deviation. The research question shows the insignificance with respect to the gender based group differences.

The data regarding the demographic group mean differences with respect to gender given in Table 8 . The table above shows that the

\begin{tabular}{|c|l|c|c|c|c|}
\hline \multicolumn{2}{|c|}{} & Frequency & Percent & $\begin{array}{c}\text { Valid } \\
\text { Percent }\end{array}$ & $\begin{array}{c}\text { Cumulative } \\
\text { Percent }\end{array}$ \\
\hline \multirow{3}{*}{ Valid } & Normal & 15 & 15.0 & 15.0 & 15.0 \\
\cline { 2 - 6 } & Deficient & 38 & 38.0 & 38.0 & 53.0 \\
\cline { 2 - 6 } & Insufficient & 47 & 47.0 & 47.0 & 100.0 \\
\cline { 2 - 6 } & Total & 100 & 100.0 & 100.0 & \\
\hline
\end{tabular}

Table 4: The frequencies regarding the calcium.

\begin{tabular}{|c|l|c|c|c|c|}
\hline \multicolumn{2}{|c|}{} & Frequency & Percent & $\begin{array}{c}\text { Valid } \\
\text { Percent }\end{array}$ & $\begin{array}{c}\text { Cumulative } \\
\text { Percent }\end{array}$ \\
\hline \multirow{3}{*}{ Valid } & Normal & 15 & 15.0 & 15.0 & 15.0 \\
\cline { 2 - 6 } & Deficient & 38 & 38.0 & 38.0 & 53.0 \\
\cline { 2 - 6 } & Insufficient & 47 & 47.0 & 47.0 & 100.0 \\
\cline { 2 - 6 } & Total & 100 & 100.0 & 100.0 & \\
\hline
\end{tabular}

Table 5: The frequencies regarding the phosphorus.

\begin{tabular}{|c|c|c|c|c|c|}
\hline \multicolumn{2}{|c|}{} & Frequency & Percent & $\begin{array}{c}\text { Valid } \\
\text { Percent }\end{array}$ & $\begin{array}{c}\text { Cumulative } \\
\text { Percent }\end{array}$ \\
\hline \multirow{3}{*}{ Valid } & Normal & 15 & 15.0 & 15.0 & 15.0 \\
\cline { 2 - 6 } & Deficient & 38 & 38.0 & 38.0 & 53.0 \\
\cline { 2 - 6 } & Insufficient & 47 & 47.0 & 47.0 & 100.0 \\
\cline { 2 - 6 } & Total & 100 & 100.0 & 100.0 & \\
\hline
\end{tabular}

Table 6: The frequencies regarding the alkaline phosphatase.

\begin{tabular}{|l|c|c|c|c|c|}
\hline & N & Minimum & Maximum & Mean & $\begin{array}{c}\text { Std. } \\
\text { Deviation }\end{array}$ \\
\hline Gender & 100 & 1 & 2 & 1.37 & 0.485 \\
\hline Age & 100 & 1 & 3 & 1.93 & 0.832 \\
\hline Vitamin D & 100 & 1 & 3 & 2.32 & 0.723 \\
\hline Calcium & 100 & 1 & 3 & 2.32 & 0.723 \\
\hline Phosphorus & 100 & 1 & 3 & 2.32 & 0.723 \\
\hline Alkaline Phosphatase & 100 & 1 & 3 & 2.32 & 0.723 \\
\hline Valid N (list wise) & 100 & & & & \\
\hline
\end{tabular}

Table 7: The descriptive statistics regarding the research questions.

\begin{tabular}{|l|c|c|c|c|c|c|}
\hline & Gender & N & Mean & $\begin{array}{c}\text { Std. } \\
\text { Deviation }\end{array}$ & F & Sig. \\
\hline \multirow{2}{*}{ Vitamin D } & Male & 63 & 2.24 & 0.712 & & \\
\hline \multirow{2}{*}{ Calcium } & Female & 37 & 2.46 & 0.730 & 0.270 & 0.605 \\
\hline \multirow{2}{*}{ Phosphorus } & Male & 63 & 2.24 & 0.712 & & \\
\cline { 2 - 7 } & Female & 37 & 2.46 & 0.730 & 0.270 & 0.605 \\
\hline Alkaline & Male & 63 & 2.24 & 0.712 & & \\
\hline Phosphatase & Memale & 37 & 2.46 & 0.730 & 0.270 & 0.605 \\
\cline { 2 - 7 } & Female & 63 & 2.24 & 0.712 & & \\
\hline
\end{tabular}

Table 8: The group statistics regarding gender-based mean differences (T-test). 
patients have similar opinions regarding all the research questions and none of the research variable shown its significance with respect to gender. The table above provided the data with respect to the total number (100), the mean and the standard deviation. The research question shows the insignificance with respect to the gender based group differences $[11,12]$.

\section{Discussion}

Vitamin D is produced by the skin exposed to direct sunshine and is also provided by the nutrients. Each of these two sources can provide a sufficient supply, but if one of them is reduced the other source can easily become insufficient. Nevertheless sun effect even if the role of skin synthesis as a determinant of serum $25(\mathrm{OH}) \mathrm{D}$ has not been completely defined because of the absence of a direct measurement of personal sunshine exposure [13].

Our findings show that women were more likely to be vitamin $\mathrm{D}$ deficient than men. Vitamin D deficiency is often seen in postmenopausal women and has been associated with a greater incidence of hip fractures [14].

In our study, the influence of gender is reported in insufficiency, deficiency of vitamin D in serum, female is more affected (67\%) as compared to male (37\%). Our results are in accordance with [15-17]. Cultural dress (e.g. burkhas) is potentially a major contributor to reduced vitamin $\mathrm{D}_{3}$ concentrations as the majority of the Asian population studied are of Pakistani origin. Since female Asians cover the majority of their bodies (e.g. purdah) this in turn will reduce the exposure to sunlight all year round and thus vitamin $\mathrm{D}_{3}$ production [18]. Vitamin $\mathrm{D}_{3}$ levels will therefore be depleted as an estimated $90 \%$ of the vitamin is produced in vivo unless replaced through diet or supplementation [19].

Vitamin D is a fundamentally important hormone involved in calcium absorption, bone mineralization and parathyroid hormone production. Vitamin D insufficiency and deficiency is involved in calcium and phosphorus absorption in the serum and availability in food, diet and intake. There is low calcium and phosphorus level associated with insufficiency and deficiency as proposed by Willis et al. [18].

In this study, the result of ANOVA shows highly significance with the role of alkaline phosphate level of serum and vitamin $\mathrm{D}$ in sufficiency and deficiency.

\section{Conclusion}

In conclusion, we found that the vitamin $\mathrm{D}$ deficiency and insufficiency is associated with the levels of Calcium, Phosphate, Alkaline phosphate and gender and age of suspects. If normal levels of Calcium, phosphate and normal functioning of alkaline phosphate enzyme may lead to normal vitamin D level which is the overall health of bones and skeleton and body.

\section{Facts and Findings}

I made recommendation for future studies based on our study findings and needs of D. G. Khan population. As well, I suggested some possible programs to increases Vitamin D level among D.G. Khan population living in south Punjab and perhaps to some extents provides to awareness to the Punjab health authorities of the Vitamin D status of their populations and if possible encourage them to take positive step forward to improve their populations health.

\section{Recommendation}

The following preventive strategies are made for avoiding vitamin
D Insufficiency and Deficiency. The vitamin D Insufficient and Deficient patients should be used proper amount of foods and those foods which contain proper amount of vitamin D such as Code liver oil, Swordfish, Salmon, Orange juice, Milk, Margarine, Sardine, Liver, Beef, Eggs, Cereals. The major source of Vitamin D for children and adults is exposure to natural sunlight.

\section{Acknowledgement}

In the present world of competition there is a race of existence in which those are having will to come forward and succeed. Project is like a bridge between theoretical and practical work. With this willing I joined this particular project. At las but not the least I am thankful to all my teachers and friends who have always been helping and encouraging to me throughout the year

\section{References}

1. Harbour R, Miller J (2001) A new system for grading recommendations in evidence based guidelines. BMJ 323: 334-336.

2. 2. Holick MF, Biancuzzo RM, Chen TC, Klein EK, Young A, et al. (2008) Vitamin D2 is as effective as vitamin D3 in maintaining circulating concentrations of 25-hydroxyvitamin D. J Clin Endocrinol Metab 93: 677-681.

3. Thacher TD, Obadofin MO, O'Brien KO, Abrams SA (2009) The effect of vitamin D2 and vitamin D3 on intestinal calcium absorption in Nigerian children with rickets. J Clin Endocrinol Metab 94: 3314-3321.

4. Bingham CT, Fitzpatrick LA (1993) Noninvasive testing in the diagnosis of osteomalacia. Am J Med 95: 519-523.

5. 5. Priemel M, von Domarus C, Klatte TO, Kessler S, Schlie J, et al. (2010) Bone mineralization defects and vitamin $D$ deficiency: Histomorphometric analysis of iliac crest bone biopsies. and circulating 25-hydroxyvitamin $D$ in 675 patients. $J$ Bone Miner Res 25: 305-312.

6. 6. Bischoff-Ferrari HA, Willett WC, Wong JB, Stuck AE, Staehelin HB, et al (2009) Prevention of non-vertebral fractures with oral vitamin $D$ and dose dependency: a meta-analysis of randomized controlled trials. Arch Intern Med 169: 551.

7. 7. Bischoff-Ferrari HA, Dawson-Hughes B, Staehelin HB, Orav JE, Stuck AE, et al. (2009) Fall prevention with supplemental and active forms of vitamin D: a meta-analysis of randomised controlled trials. BMJ 339: b3692.

8. 8.Holick MF, Schnoes HK, DeLuca HF, Suda T, Cousins RJ (1971) Isolation and identification of 1,25-dihydroxycholecalciferol. A metabolite of vitamin $D$ active in intestine. Biochemistry 10: 2799-2804.

9. Mir Sadat-Ali, El-Abdulmohsen Al, Al-Turki H, Al-Mulhim F, Al-Ali A (2009) Vitamin D levels in healthy men in eastern Saudi Arabia. Ann Saudi Med 29: 378

10. Siddiqui AM, Kamfar HZ (2007) Prevalence of vitamin D deficiency rickets in adolescent schoolgirls in Western region, Saudi Arabia. Saudi Med J 28: 441444

11. Steingrimsdottir L, Gunnarsson O, Indridason OS, Franzson L, Sigurdsson G (2005) Relationship between serum parathyroid hormone levels, vitamin D sufficiency and calcium intake. JAMA 294:2336-2341.

12. Laisa T, Jacqueline B, Bogda K, Michael GK, Euan W, et al. (2013) Clinica outcomes of vitamin $\mathrm{D}$ deficiency and supplementation in cancer patients. Nutr Rev 71: 611-621.

13. Thacher TD, Fischer PR, Strand MA, Pettifor JM (2006) Nutritional rickets around the world: Causes and future directions. Ann Trop Paediatr 26: 1-16.

14. Vacek JL, Vanga SR, Good M, Lai SM, Lakkireddy D, et al. (2012) Vitamin $\mathrm{D}$ deficiency and supplementation and relation to cardiovascular health. Am J Cardiol 109: 359-363.

15. van der Wielen RP, Lowik MR, van den Berg H, de Groot LC, Haller J, et al. (1995) Serum vitamin D concentrations among elderly people in Europe. Lancet 346: 207-210.

16. Vieth R, Cole DE, Hawker GA, Trang HM, Rubin LA (2001) Wintertime vitamin $D$ insufficiency is common in young Canadian women and their vitamin D intake does not prevent it. Eur J Clin Nutr 55: 1091-1097.

17. Reinhold V (1999) Vitamin D supplementation, 25-hydroxyvitamin D concentrations and safety. Am J Clin Nutr 69: 842-856. 
Citation: Ahmad A (2018) Chemical Analysis of Vitamin D Insufficient and Vitamin D Deficient Patient in Dera Ghazi Khan. Mol Biol 7: 211. doi: 10.4172/2168-9547.1000211

18. Willis KS, Peterson NJ, Larson-Meyer DE (2008) Should we be concerned about the vitamin D status of athletes? Int J Sport Nutr Exerc Metab 18: 204 224
19. Wu K, Feskanich D, Fuchs CS, Willett WC, Hollis BW, et al. (2007) A nested case-control study of plasma 25-hydroxyvitamin D concentrations and risk of colorectal cancer. J Natl Cancer Inst 99: 1120-1129. 